\title{
PERANAN PAJAK UNTUK MENINGKATKAN KEMANDIRIAN ANGGARAN
}

\author{
Joko Waluyo \\ Fakultas Ekonomi Universitas Pembangunan Nasional "Veteran" Yogyakarta \\ E-mail: waluyo01@yahoo.com
}

\begin{abstract}
The main subject of this paper are the role of tax revenue to central government budget and how reforms it to increase tax revenue. Financing budget deficits represent one of cause of state budget become annoyed. Ratio tax - PDB ranging from 13 - 15 percent showing good improvement, although still not yet optimal. Ratio taxrevenue and tax - expenditure progressively mount which indication that important taxation role progressively in budget revenue sources. In year of the research showing by change of tax structure from oil tax become the non oil tax, and also from indirect tax become to the direct taxes. Role of direct taxes progressively mount in taxation structure. Tax effort indicator and elasticity of tax revenue indicate that the good imposition efficiency progressively. To increase tax revenue without giving distortion to economics require to be conducted by a taxation reform.
\end{abstract}

Key word: tax ratio, tax effort, tax base, tax reform

\section{PENDAHULUAN}

Secara ekonomi kemandirian sebuah bangsa dapat diukur dari kemandirian pembiayaan pengeluaran pemerintah yang tercermin dalam anggaran negara. Kemandirian anggaran negara dibutuhkan untuk mengantisipasi pembiayaan pembangunan yang semakin meningkat. Meningkatnya kebutuhan pembangunan salah satunya disebabkan oleh semakin bertambahnya tugas dan fungsi suatu pemerintahan untuk menyediakan barang dan jasa untuk kebutuhan publik, misalnya: kebutuhan akan pendidikan, keamanan dan pertahanan (Soetrisno; 1984). Kemandirian anggaran negara juga mempengaruhi stabilitas perekonomian nasional, jika terjadi gejolak eksternal perekonomian dunia maka rela- tif cepat untuk melakukan recovery perekonomian ${ }^{1}$. Secara politis kemandirian keuangan negara akan mengurangi tekanan-tekanan terhadap arah, tujuan, dan sasaran pembangunan nasional, sehingga tujuan kemerdekaan akan lebih cepat tercapai.

Sebuah anggaran negara disebut mandiri jika semua pengeluaran pemerintah dapat dibiayai dengan kemampuan pemerintah sendiri. Salah satu kemampuan pemerintah untuk menghimpun dana masyarakat yaitu dengan melalui instrumen perpajakan. Instru-

1 Studi lebih lanjut tentang hal ini dapat dilihat dalam Joko Waluyo, 2005, Implikasi Pembiayaan Defisit Anggaran Pemerintah Pusat Terhadap Inflasi dan Pertumbuhan Ekonomi: Studi Kasus Indonesia tahun 1970-2003, Tesis Pasacasarjana, Fakultas Ekonomi, Universitas Indonesia, Depok, (Tidak dipublikasikan). 
men perpajakan merupakan instrumen legal pemerintah untuk memobilisasi dana masyarakat, sebab berdasarkan undang-undang yang disetujui dan disahkan oleh wakil-wakil rakyat di DPR. Walaupun tidak menutup kemungkinan pemerintah dapat memobilisasi dana masyarakat melalui penerimaan non pajak, misalnya dari penerimaan keuntungan perusahaan negara, penerbitan obligasi, kontrak bagi hasil dengan perusahaan swasta ${ }^{2}$. Sumber penerimaan ini memerlukan "effort" tambahan, initial value tertentu dan kadangkadang akan mendistorsi perekonomian ${ }^{3}$.

Kemandirian anggaran negara sangat dipengaruhi pula oleh struktur penerimaan dan pengeluaran negara, serta kebijakan anggaran yang digunakan. Di negara terbelakang dan berkembang biasanya belum mempunyai sumber pertumbuhan ekonomi yang luas sehingga basis pajaknya relatif terbatas. Kebijakan anggaran defisit merupakan alternatif terbaik untuk meningkatkan pertumbuhan ekonomi, sehingga diharapkan basis pajak yang ada meningkat yang pada akhirnya akan meningkatkan penerimaan negara. Adanya item pembiayaan defisit anggaran inilah yang menyebabkan kemandirian keuangan negara menjadi terganggu. Pembiayaan defisit anggaran secara garis besar adalah utang, karena pemerintah menggunakan pembiayaan di luar

2 Di negara-negara sedang berkembang penerimaan non perpajakan merupakan instrumen penting dalam penerimaan negara, sehingga harus diperhitungkan dalam menganalisis defisit anggaran. Lihat misalnya: Agenor dan Montiel (1996), Agenor (1999), dan Geithner(2003).

3 Misalnya pemerintah harus mendirikan dan mengelola perusahaan negara dan memerlukan gestation periode sampai menguntungkan. Kontrak bagi hasil minyak dan gas bumi mensyaratkan sumber migas yang cukup untuk dieksploitasi. Kebijakan menerbitkan obligasi negara bisa menyebabkan terjadinya fenomena crowding out effect terhadap investasi swasta, sehingga pertumbuhan ekonomi akan terganggu (lihat dalam Joko Waluyo, ibid). kemampuannya untuk menghimpun dana masyarakat melalui sistem perpajakan (Garcia; 2003). Utang luar negeri yang besar di samping akan menambah beban anggaran juga akan mempengaruhi penentuan kebijakan pembangunan nasional.

Di Indonesia, hampir semua rezim pemerintahan yang berkuasa menjalankan kebijakan anggaran defisit, yang berbeda hanyalah sumber pembiayaannya. Pembiayaan defisit anggaran didanai dengan menggunakan utang luar negeri selama pemerintahan orde baru. Hal ini karena trauma inflasi tinggi ketika defisit dibiayai dengan pencetakan uang (printing money) pada masa rezim orde lama (Nasution, 1983, 1984). Pemerintahan orde reformasi saat ini berusaha memobilisasi dana masyarakat dengan menerbitkan obligasi negara untuk pembiayaan defisit. Beban defisit anggaran terhadap perekonomian negara semakin meningkat yang dicerminkan oleh semakin meningkatnya rasio defisit terhadap PDB. Rasio defisit terhadap PDB mengalami kenaikan menjadi sebesar 3,73 persen pada tahun 1998 dan 4,18 persen pada tahun 2001, sedangkan rata-rata selama krisis di atas 2 persen (Lampiran 1). Berarti beban PDB untuk menutup defisit anggaran pemerintah semakin meningkat.

Krisis ekonomi menyebabkan semakin meningkatnya beban bunga dan cicilan utang luar negeri. Pada tahun 1998 pemerintah menerbitkan Surat Utang Negara (SUN) untuk menyelamatkan sektor perbankan dari systematic insolvency. Hal ini berdampak terhadap meningkatnya beban total utang pemerintah yang dicerminkan oleh semakin meningkatnya rasio beban utang terhadap PDB, yaitu sebesar 83,78 persen tahun 1999 , dan 108,04 persen tahun 2000 (lampiran 1). Rasio ini tidak sesuai dengan standar yang 
telah digariskan oleh undang-undang yaitu sebesar 3 persen dan 60 persen terhadap $\mathrm{PDB}^{4}$. Fakta ini menunjukkan bahwa penerimaan negara yang mampu dihimpun oleh pemerintah tidak bisa mengimbangi besarnya pengeluaran yang dilakukan. Idealnya pemerintah harus mampu menghemat pengeluarannya dan meningkatkan penerimaannya, sehingga besarnya defisit anggaran tidak semakin membesar. Pada sisi yang lain rasio pajak terhadap PDB masih belum optimal, yaitu masih di bawah 20 persen. Fakta ini menunjukkan bahwa masih terbuka kemungkinan pemerintah melakukan peningkatan penerimaan negara melalui sektor perpajakan.

Pertanyaan yang menarik diajukan adalah bagaimanakah peranan penerimaan pajak terhadap kemandirian anggaran negara? Bagaimanakah kebijakan yang harus ditempuh pemerintah untuk meningkatkan penerimaan pajak? Untuk memudahkan menjawab permasalahan yang diajukan maka paper ini dibagi dalam beberapa sub bagian, yaitu: Diawali dengan pembahasan mengenai struktur penerimaan pemerintah dan perpajakan di Indonesia. Bagian kedua membahas tentang indikator peranan pajak terhadap pembiayaan anggaran negara. Bagian ketiga membahas tentang indikator efisiensi pemungutan pajak. Bagian selanjutnya berisi tentang diskusi beberapa kebijakan perpajakan yang dapat diterapkan oleh pemerintah Indonesia, dan diakhiri dengan catatan penutup sebagai suatu kesimpulan.

4 Berdasarkan Undang-Undang RI No. 17 Tahun 2003, tentang Keuangan Negara dan PP No. 17 Tahun 2003 tentang jumlah kumulatif defisit dan utang pemerintah pusat dan daerah bahwa besarnya jumlah kumulatif defisit anggaran pemerintah pusat dan daerah maksimal sebesar 3 persen terhadap PDB dan rasio utang terhadap PDB sebesar 60 persen.

\section{PEMBAHASAN}

\section{Struktur Penerimaan Pemerintah dan Perpajakan di Indonesia}

Studi tentang struktur penerimaan pemerintah dan perpajakan memberikan pengertian tentang sistem perpajakan (tax system) di suatu negara. Sistem perpajakan tidak sama di setiap negara, sangat tergantung oleh peranan pajak sebagai sumber penerimaan negara dan proporsinya dalam pembentukan Produk Domestik Bruto (PDB). Perpajakan mempunyai dua peranan penting dalam suatu perekonomian, yaitu: sebagai sumber penerimaan bagi pemerintah dan sebagai salah satu alat kebijakan pemerintah, antara lain untuk redistribusi pendapatan dan pengendalian ekonomi makro. Sehingga dalam penentuan tingkat pajak (tax rate) minimal harus mempertimbangkan kedua aspek tersebut.

Sumber penerimaan pemerintah meliputi beberapa jenis, yaitu: Satu; Kekayaan negara (state asset); dengan catatan asset tersebut dijual atau disewakan kemudian hasil penjualan atau sewanya dimasukkan ke kas negara (privatisasi). Dua; Hutang; baik ke luar negeri maupun ke dalam negeri (obligasi). Tiga; Hibah (grant), hibah yang berasal dari luar negeri maupun dalam negeri. Empat; Pencetakan uang (money creation), berkaitan dengan inflation tax, nilai riil dari pemungutan pajak. Lima; Penerimaan pajak dan pungutan-pungutan resmi yang lain (Soetrisno, $\mathrm{Ph}$; 1984). Sumber penerimaan pertama, kedua, dan keempat dalam sistem pencatatan APBN yang baru didefinisikan sebagai sumber pembiayaan defisit anggaran, Sedangkan pada APBN versi lama dimasukkan sebagai item penerimaan pemerintah ${ }^{5}$. Hibah biasanya

5 Di Indonesia mengalami 3 sistem pencatatan APBN

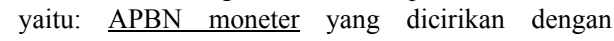


reformasi perpajakan antara lain: Penentuan basis pajak dan peninjauan tarif pajak baru, harmonisasi pungutan antar berbagai tingkat pemerintahan, dan perbaikan administrasi perpajakan untuk mengurangi tax evasion dan tax flight.

\section{DAFTAR PUSTAKA}

Agenor, Pierre Richard dan Peter Montiel, 1996. Development Macroeconomics, New Jersey: Princenton University Press.

Agenor, Pierre Richard, 1999. The Economics of Adjustment and Growth. New York: Academic Press.

Auriol, Emmanuelle and Michael Warlters, 2002. Taxation Base in Developing Countries November 25, ISPE Conference on Public Finance and Development.

Bird, Richard M and Oldman Oliver, 1990. Taxation in Developing Countries". $4^{\text {th }}$, Baltimore, Maryland: The Johns Hopkins Press Ltd.

Subiyantoro, Heru, dan Singgih Riphat, 2004. Kebijakan Fiskal, Jakarta: Penerbit Buku Kompas.

Bovenberga, A. Lans, and Ruud A. de Mooijb, 1997, Environmental Tax Reform and Endogenous Growth, Journal of Public Economics, Vol. 63, Issue 2 , January 1997, Pages 207-237.

Geithner, Timothy, 2003. SustainabilityAssessments: Review of Application and Methodological Refinements. IMF Policy Development and Review Department, Washington: IMF.

Ginting, Edimon, 1999. Tax Evasion in A Corrupt Economy. General Paper No. G-133, Centre for Policy Studies,
Monash University, Oktober

Leuthold, Jane, 2001. Taxation in Developing Countries, Manuscript University of Illinois at Urbana Champaign (Tidak dipublikasikan).

Musgrave, Richard A, 1959. The Theory of Public Finance: A Study of Public Economics. New York: McGraw-Hill.

Musgrave, Richard, A, 1989. Public Finance: Theory and Practice. $4^{\text {th }} \mathrm{ed}$, New York: McGrawhill.

Nasution, Anwar, 1984. Tinjauan Triwulanan Perekonomian Indonesia. Ekonomi dan Keuangan Indonesia, Vol. XXXII, No. I, hlm. 3-29.

Nasution, Anwar, 1984. Aspek Ekonomi Anggaran Belanja Negara. Prisma, edisi 5 Mei 1984, hlm.18-31. Jakarta: LP3ES.

Rosen, Harvey, 1998. Public Finance. Richard D. Irwin.

Sanyal, Amal, Gang N. Ira dan Goswani, Omkar, 1998. Corruption, Tax Evasion and Laffer Curve. Public Choice Centre Working Paper, George Mason University.

Slemrod, Joel, 1989. Optimal Taxation and Optimal Tax System. NBER Working Paper No. 3038, July.

Soetrisno, Ph; 1984. Dasar-Dasar Ilmu Keuangan Negara”. Yogyakarta: BPFE.

Waluyo, Joko, 2005. Implikasi Pembiayaan Defisit Anggaran Pemerintah Pusat terhadap Inflasi dan Pertumbuhan Ekonomi: Studi Kasus Indonesia tahun 19702003. Tesis Pascasarjana Ilmu Ekonomi Universitas Indonesia Depok (Tidak Dipublikasikan).

Departemen Keuangan Republik Indonesia. 
"Nota Keuangan dan RAPBN." Behun penerbitan

berapa tahun penerbitan.

Badan Pusat Statistik Indonesia.'Indikator

IMF. "Government Finance Statistics Year

Ekonomi." Beberapa tahun penerbitan.

Books." Washington DC, Beberapa ta-

\section{LAMPIRAN}

Lampiran 1. Tabel Rasio Defisit-GDP dan Rasio Utang-GDP Indonesia Tahun 1969 - 2004 (dalam \%)

\begin{tabular}{rccccc}
\hline \multirow{2}{*}{ Tahun } & Rasio & Rasio & Tahun & Rasio & Rasio \\
\cline { 2 - 3 } & Defisit - GDP & Utang - GDP & & Defisit - GDP & Utang - GDP \\
\hline 1969 & 0,03 & 2,86 & 1987 & 0,76 & 4,32 \\
1970 & 0,04 & 2,98 & 1988 & 1,31 & 6,78 \\
1971 & 0,04 & 2,96 & 1989 & 1,02 & 4,64 \\
1972 & 0,04 & 2,66 & 1990 & 0,60 & 3,97 \\
1973 & 0,04 & 2,12 & 1991 & 1,03 & 3,99 \\
1974 & 0,06 & 1,93 & 1992 & 1,18 & 3,93 \\
1975 & 0,12 & 3,56 & 1993 & 1,20 & 3,26 \\
1976 & 0,08 & 2,10 & 1994 & 0,74 & 2,57 \\
1977 & 0,03 & 1,33 & 1995 & 0,51 & 2,46 \\
1978 & 0,09 & 1,93 & 1996 & 0,83 & 10,38 \\
1979 & 0,16 & 2,42 & 1997 & 1,14 & 8,58 \\
1980 & 0,21 & 2,47 & 1998 & 3,73 & 7,04 \\
1981 & 0,29 & 2,68 & 1999 & 2,48 & 83,78 \\
1982 & 0,36 & 3,21 & 2000 & 2,35 & 108,04 \\
1983 & 0,41 & 3,28 & 2001 & $\mathbf{4}, 18$ & 95,09 \\
1984 & 0,30 & 1,98 & 2002 & 2,98 & 82,78 \\
1985 & 0,44 & 2,88 & 2003 & 2,43 & $\mathbf{7 2 , 2 7}$ \\
1986 & 0,80 & 4,98 & 2004 & 2,34 & $\mathbf{8 0 , 9 6}$ \\
\hline
\end{tabular}

Keterangan : Tahun 69 menunjukkan tahun anggaran 1969-1970 dan seterusnya, kecuali mulai tahun 2000. Sumber: IMF, Government Finance Statistics Year Books, Berbagai Tahun(diolah), Depkeu RI, Nota Keuangan dan RAPBN, Berbagai Tahun (diolah), BPS, Indikator Ekonomi, Berbagai Tahun (diolah). 
Lampiran 2. Tabel Struktur Penerimaan Pemerintah Pusat Indonesia Tahun 1969 - 2004 (dalam Persen (\%))

\begin{tabular}{|c|c|c|c|c|c|}
\hline \multirow{2}{*}{ Tahun } & \multicolumn{3}{|c|}{ Penerimaan Perpajakan } & \multirow{2}{*}{$\begin{array}{l}\text { Penerimaan } \\
\text { Bukan Pajak }\end{array}$} & \multirow{2}{*}{ Hibah } \\
\hline & Dalam Negeri & $\begin{array}{l}\text { Perdagangan } \\
\text { Internasional }\end{array}$ & Lainnya & & \\
\hline 1970 & 30.09 & 33.85 & 1.27 & 34.79 & 0.00 \\
\hline 1971 & 37.49 & 23.54 & 1.60 & 37.37 & 0.00 \\
\hline 1972 & 37.33 & 18.72 & 1.25 & 42.70 & 0.00 \\
\hline 1973 & 34.14 & 20.37 & 1.58 & 43.92 & 0.00 \\
\hline 1974 & 27.63 & 13.05 & 0.98 & 58.34 & 0.00 \\
\hline 1975 & 27.77 & 12.88 & 0.87 & 58.48 & 0.00 \\
\hline 1976 & 28.62 & 11.11 & 0.42 & 59.86 & 0.00 \\
\hline 1977 & 29.53 & 10.60 & 0.38 & 59.49 & 0.00 \\
\hline 1978 & 29.19 & 11.28 & 0.41 & 59.11 & 0.00 \\
\hline 1979 & 22.63 & 11.00 & 0.29 & 66.08 & 0.00 \\
\hline 1980 & 21.18 & 7.86 & 0.27 & 70.69 & 0.00 \\
\hline 1981 & 20.83 & 5.22 & 0.28 & 73.67 & 0.00 \\
\hline 1982 & 25.30 & 4.85 & 0.32 & 69.53 & 0.00 \\
\hline 1983 & 22.99 & 4.25 & 0.29 & 72.48 & 0.00 \\
\hline 1984 & 25.12 & 3.93 & 1.03 & 69.91 & 0.00 \\
\hline 1985 & 25.34 & 3.45 & 1.44 & 69.77 & 0.00 \\
\hline 1986 & 39.29 & 7.76 & 1.74 & 51.21 & 0.00 \\
\hline 1987 & 36.91 & 7.46 & 1.33 & 54.30 & 0.00 \\
\hline 1988 & 45.15 & 6.48 & 1.09 & 47.28 & 0.00 \\
\hline 1989 & 43.89 & 6.56 & 0.61 & 48.95 & 0.00 \\
\hline 1990 & 49.71 & 6.15 & 0.47 & 43.68 & 0.00 \\
\hline 1991 & 54.54 & 6.30 & 0.65 & 38.51 & 0.00 \\
\hline 1992 & 58.50 & 6.03 & 0.47 & 35.00 & 0.00 \\
\hline 1993 & 62.91 & 5.68 & 0.45 & 30.95 & 0.00 \\
\hline 1994 & 65.64 & 5.26 & 0.39 & 28.70 & 0.00 \\
\hline 1995 & 65.50 & 3.96 & 0.56 & 29.98 & 0.00 \\
\hline 1996 & 64.50 & 2.81 & 0.63 & 32.06 & 0.00 \\
\hline 1997 & 62.57 & 2.60 & 0.40 & 34.43 & 0.00 \\
\hline 1998 & 63.02 & 4.07 & 0.24 & 32.67 & 0.00 \\
\hline 1999 & 59.80 & 2.49 & 0.28 & 37.43 & 0.00 \\
\hline 2000 & 55.67 & 3.16 & 0.50 & 40.68 & 0.00 \\
\hline 2001 & 59.65 & 3.34 & 0.53 & 36.32 & 0.15 \\
\hline 2002 & 67.95 & 3.74 & 0.45 & 27.78 & 0.08 \\
\hline 2003 & 73.27 & 3.43 & 0.60 & 22.70 & 0.00 \\
\hline 2004 & 74.16 & 3.41 & 0.46 & 21.80 & 0.18 \\
\hline Rata-Rata & 44.22 & 8.19 & 0.70 & 46.88 & 0.01 \\
\hline
\end{tabular}

Keterangan : Tahun 69 menunjukan tahun anggaran 1969-1970 dan seterusnya, kecuali mulai tahun 2000.

Sumber : IMF, Government Finance Statistics Year Books, Berbagai Tahun(diolah), Depkeu RI, Nota Keuangan dan RAPBN, Berbagai Tahun (diolah), BPS, Indikator Ekonomi, Berbagai Tahun (diolah). 
Lampiran 3. Tabel Struktur Penerimaan Perpajakan Pemerintah Pusat Indonesia Tahun 1970 - 2004 (dalam Persen (\%))

\begin{tabular}{|c|c|c|c|c|c|c|c|c|c|}
\hline Tahun & $\begin{array}{c}\text { PPh } \\
\text { Non Migas }\end{array}$ & $\begin{array}{l}\text { PPh } \\
\text { Migas }\end{array}$ & PBB & BPHTB & $\begin{array}{l}\text { PPN dan } \\
\text { PPn BM }\end{array}$ & Cukai & Bea Masuk & $\begin{array}{l}\text { Pajak } \\
\text { Ekspor }\end{array}$ & $\begin{array}{l}\text { Pajak } \\
\text { Lainnya }\end{array}$ \\
\hline 1970 & 16.99 & 23.76 & 0.00 & 0.00 & 13.74 & 4.45 & 32.25 & 7.32 & 1.48 \\
\hline 1971 & 20.84 & 30.31 & 0.05 & 0.00 & 10.57 & 10.25 & 18.56 & 7.64 & 1.78 \\
\hline 1972 & 16.99 & 36.69 & 2.50 & 0.00 & 12.58 & 9.17 & 14.21 & 6.48 & 1.38 \\
\hline 1973 & 15.88 & 38.85 & 2.85 & 0.00 & 11.49 & 7.00 & 14.41 & 7.79 & 1.72 \\
\hline 1974 & 13.55 & 56.48 & 1.75 & 0.00 & 9.09 & 4.48 & 9.46 & 4.17 & 1.02 \\
\hline 1975 & 14.16 & 56.30 & 1.70 & 0.00 & 9.35 & 4.01 & 10.70 & 2.86 & 0.92 \\
\hline 1976 & 13.83 & 57.97 & 1.70 & 0.00 & 9.59 & 4.85 & 9.29 & 2.35 & 0.43 \\
\hline 1977 & 14.55 & 57.65 & 2.38 & 0.00 & 8.72 & 5.21 & 8.70 & 2.38 & 0.40 \\
\hline 1978 & 14.05 & 56.60 & 2.92 & 0.00 & 8.20 & 5.81 & 8.02 & 3.95 & 0.44 \\
\hline 1979 & 12.20 & 65.10 & 1.14 & 0.00 & 5.06 & 4.87 & 5.37 & 5.95 & 0.30 \\
\hline 1980 & 11.49 & 69.94 & 0.98 & 0.00 & 4.78 & 4.47 & 4.94 & 3.12 & 0.27 \\
\hline 1981 & 11.36 & 72.93 & 0.86 & 0.00 & 4.74 & 4.45 & 4.29 & 1.08 & 0.28 \\
\hline 1982 & 14.05 & 68.40 & 0.97 & 0.00 & 5.92 & 5.30 & 4.33 & 0.69 & 0.34 \\
\hline 1983 & 12.43 & 71.59 & 0.99 & 0.00 & 5.13 & 5.18 & 3.73 & 0.65 & 0.29 \\
\hline 1984 & 13.42 & 68.51 & 1.40 & 0.00 & 5.74 & 5.74 & 3.56 & 0.56 & 1.08 \\
\hline 1985 & 10.76 & 67.13 & 0.86 & 0.00 & 11.38 & 4.57 & 3.50 & 0.25 & 1.56 \\
\hline 1986 & 17.16 & 44.08 & 1.58 & 0.00 & 19.68 & 6.61 & 8.37 & 0.53 & 1.99 \\
\hline 1987 & 14.37 & 50.38 & 1.06 & 0.00 & 19.12 & 5.52 & 7.20 & 0.90 & 1.44 \\
\hline 1988 & 20.26 & 43.58 & 1.65 & 0.00 & 19.96 & 6.45 & 6.29 & 0.64 & 1.17 \\
\hline 1989 & 19.53 & 45.41 & 2.05 & 0.00 & 20.32 & 5.03 & 6.42 & 0.59 & 0.65 \\
\hline 1990 & 20.75 & 44.63 & 1.98 & 0.00 & 20.43 & 4.53 & 7.04 & 0.10 & 0.54 \\
\hline 1991 & 24.32 & 37.68 & 2.36 & 0.00 & 22.87 & 4.79 & 7.18 & 0.04 & 0.75 \\
\hline 1992 & 27.56 & 33.75 & 2.44 & 0.00 & 23.65 & 4.94 & 7.10 & 0.02 & 0.56 \\
\hline 1993 & 30.02 & 25.43 & 3.02 & 0.00 & 28.36 & 5.34 & 7.23 & 0.03 & 0.58 \\
\hline 1994 & 32.36 & 23.35 & 2.84 & 0.00 & 28.54 & 5.44 & 6.73 & 0.23 & 0.52 \\
\hline 1995 & 32.46 & 24.80 & 2.93 & 0.00 & 28.61 & 5.55 & 4.68 & 0.29 & 0.70 \\
\hline 1996 & 34.93 & 25.99 & 3.11 & 0.00 & 26.27 & 5.50 & 3.33 & 0.10 & 0.76 \\
\hline 1997 & 33.88 & 30.11 & 2.60 & 0.00 & 24.83 & 5.03 & 2.95 & 0.13 & 0.47 \\
\hline 1998 & 38.91 & 28.78 & 2.48 & 0.00 & 19.34 & 5.38 & 1.60 & 3.22 & 0.29 \\
\hline 1999 & 34.84 & 34.14 & 2.01 & 0.36 & 19.32 & 6.06 & 2.44 & 0.50 & 0.33 \\
\hline 2000 & 26.20 & 38.91 & 2.05 & 0.45 & 20.58 & 6.94 & 3.99 & 0.22 & 0.66 \\
\hline 2001 & 28.62 & 33.62 & 1.97 & 0.61 & 22.93 & 7.24 & 4.04 & 0.30 & 0.69 \\
\hline 2002 & 33.20 & 24.38 & 2.30 & 0.57 & 25.82 & 8.56 & 4.51 & 0.12 & 0.55 \\
\hline 2003 & 35.91 & 19.01 & 2.55 & 0.81 & 27.33 & 9.46 & 4.05 & 0.15 & 0.73 \\
\hline 2004 & 39.87 & 14.52 & 2.65 & 0.88 & 28.47 & 9.13 & 3.84 & 0.10 & 0.53 \\
\hline Rata-rata & 22.05 & 43.45 & 1.91 & 0.11 & 16.64 & 5.92 & 7.27 & 1.87 & 0.79 \\
\hline
\end{tabular}

Keterangan : Tahun 69 menunjukkan tahun anggaran 1969-1970 dan seterusnya, kecuali mulai tahun 2000.

Sumber : IMF, Government Finance Statistics Year Books, Berbagai Tahun(diolah); Depkeu RI, Nota Keuangan dan RAPBN, Berbagai Tahun (diolah); BPS, Indikator Ekonomi, Berbagai Tahun (diolah). 
Lampiran 4. Tabel Beberapa Rasio Penerimaan Pajak Indonesia Tahun 1970-2004 (dalam Persen (\%))

\begin{tabular}{|c|c|c|c|c|}
\hline \multirow{2}{*}{ Tahun } & \multicolumn{4}{|c|}{ Rasio Pajak terhadap } \\
\hline & PDB & Defisit & Penerimaan & Pengeluaran \\
\hline 1970 & 6.61 & 2.90 & 65.21 & 51.18 \\
\hline 1971 & 7.06 & 2.79 & 62.63 & 50.93 \\
\hline 1972 & 7.43 & 3.57 & 57.30 & 49.03 \\
\hline 1973 & 8.10 & 5.48 & 56.08 & 49.45 \\
\hline 1974 & 6.89 & 5.64 & 41.66 & 37.42 \\
\hline 1975 & 7.37 & 4.65 & 41.52 & 34.83 \\
\hline 1976 & 7.44 & 2.67 & 40.14 & 36.23 \\
\hline 1977 & 7.48 & 4.59 & 40.51 & 39.29 \\
\hline 1978 & 7.63 & 15.96 & 40.89 & 37.60 \\
\hline 1979 & 7.13 & 6.15 & 33.92 & 30.54 \\
\hline 1980 & 6.41 & 3.90 & 29.31 & 26.47 \\
\hline 1981 & 5.51 & 3.00 & 26.33 & 23.26 \\
\hline 1982 & 6.04 & 2.35 & 30.47 & 26.17 \\
\hline 1983 & 5.80 & 2.21 & 27.52 & 23.99 \\
\hline 1984 & 5.33 & 1.99 & 30.09 & 26.96 \\
\hline 1985 & 6.43 & 3.42 & 30.23 & 26.65 \\
\hline 1986 & 7.66 & 3.02 & 48.79 & 37.19 \\
\hline 1987 & 7.72 & 1.83 & 45.70 & 36.63 \\
\hline 1988 & 8.26 & 2.29 & 52.72 & 37.12 \\
\hline 1989 & 8.96 & 1.63 & 51.05 & 40.48 \\
\hline 1990 & 12.34 & 3.16 & 56.32 & 54.93 \\
\hline 1991 & 11.28 & 5.45 & 61.49 & 54.10 \\
\hline 1992 & 12.34 & 3.65 & 65.00 & 57.61 \\
\hline 1993 & 13.15 & 3.72 & 69.05 & 63.13 \\
\hline 1994 & 14.28 & 4.33 & 71.30 & 73.02 \\
\hline 1995 & 12.50 & 6.81 & 70.02 & 71.72 \\
\hline 1996 & 12.05 & 10.35 & 67.94 & 65.17 \\
\hline 1997 & 12.54 & 7.24 & 65.57 & 61.54 \\
\hline 1998 & 12.00 & 7.32 & 67.33 & 56.58 \\
\hline 1999 & 11.49 & 2.83 & 62.57 & 57.89 \\
\hline 2000 & 9.58 & 4.05 & 59.32 & 54.11 \\
\hline 2001 & 13.83 & 6.74 & 63.52 & 56.54 \\
\hline 2002 & 14.54 & 4.28 & 72.14 & 67.75 \\
\hline 2003 & 15.63 & 6.90 & 77.30 & 75.35 \\
\hline 2004 & 11.89 & 7.95 & 78.02 & 73.14 \\
\hline Rata-rata & 9.45 & 4.71 & 53.11 & 47.54 \\
\hline
\end{tabular}

Keterangan : Tahun 69 menunjukan tahun anggaran 1969-1970 dan seterusnya, kecuali mulai tahun 2000.

Sumber: IMF, Government Finance Statistics Year Books, Berbagai Tahun(diolah); Depkeu RI, Nota Keuangan dan RAPBN, Berbagai Tahun (diolah); BPS, Indikator Ekonomi, Berbagai Tahun (diolah). 
Lampiran 5. Tabel Usaha Pemungutan Pajak (Tax Effort) Indonesia Tahun 1970 -2004 (dalam Persen (\%))

\begin{tabular}{|c|c|c|c|c|c|}
\hline \multirow[b]{2}{*}{ Tahun } & \multicolumn{2}{|c|}{ Tax Effort } & \multirow[b]{2}{*}{ Tahun } & \multicolumn{2}{|c|}{ Tax Effort } \\
\hline & $\begin{array}{l}\text { Tanpa } \\
\text { Migas }\end{array}$ & $\begin{array}{c}\text { Dengan } \\
\text { Migas }\end{array}$ & & $\begin{array}{l}\text { Tanpa } \\
\text { Migas }\end{array}$ & $\begin{array}{c}\text { Dengan } \\
\text { Migas }\end{array}$ \\
\hline 1970 & 8,10 & 10,68 & 1988 & 10,11 & 18,09 \\
\hline 1971 & 8,60 & 12,43 & 1989 & 11,06 & 20,37 \\
\hline 1972 & 9,08 & 14,47 & 1990 & 12,92 & 23,44 \\
\hline 1973 & 9,84 & 16,27 & 1991 & 12,31 & 19,85 \\
\hline 1974 & 8,41 & 19,58 & 1992 & 13,21 & 19,99 \\
\hline 1975 & 9,02 & 20,89 & 1993 & 13,79 & 18,53 \\
\hline 1976 & 9,20 & 22,03 & 1994 & 14,44 & 18,86 \\
\hline 1977 & 9,27 & 22,00 & 1995 & 13,27 & 17,68 \\
\hline 1978 & 9,45 & 21,89 & 1996 & 13,32 & 18,05 \\
\hline 1979 & 8,84 & 25,47 & 1997 & 14,03 & 20,12 \\
\hline 1980 & 7,94 & 26,57 & 1998 & 13,34 & 18,75 \\
\hline 1981 & 6,81 & 25,37 & 1999 & 12,76 & 19,41 \\
\hline 1982 & 7,46 & 23,79 & 2000 & 9,15 & 15,04 \\
\hline 1983 & 7,18 & 25,46 & 2001 & 13,80 & 20,86 \\
\hline 1984 & 6,44 & 20,94 & 2002 & 15,31 & 20,28 \\
\hline 1985 & 7,66 & 24,08 & 2003 & 16,60 & 20,53 \\
\hline 1986 & 9,24 & 16,79 & 2004 & 13,97 & 16,36 \\
\hline \multirow[t]{2}{*}{1987} & 9,37 & 19,17 & & & \\
\hline & & & Rata-rata & 10.72 & 19.83 \\
\hline
\end{tabular}

Keterangan : Tahun 69 menunjukan tahun anggaran 1969-1970 dan seterusnya, kecuali mulai tahun 2000.

Sumber: IMF, Government Finance Statistics Year Books, Berbagai Tahun(diolah); Depkeu RI, Nota Keuangan dan RAPBN, Berbagai Tahun (diolah); BPS, Indikator Ekonomi, Berbagai Tahun (diolah).

\section{Lampiran 6. Tabel Elastisitas Penerimaan Pajak terhadap PDB Indonesia Tahun 1971-2004 (dalam Persen (\%))}

\begin{tabular}{|c|c|c|c|c|c|c|c|c|c|c|}
\hline Tahun & $\begin{array}{c}\text { PPh } \\
\text { Non Migas }\end{array}$ & $\begin{array}{l}\text { PPh } \\
\text { Migas }\end{array}$ & PBB & ВРНТВ & $\begin{array}{l}\text { PPN dan } \\
\text { PPn BM }\end{array}$ & Cukai & $\begin{array}{c}\text { Bea } \\
\text { Masuk }\end{array}$ & $\begin{array}{l}\text { Pajak } \\
\text { Ekspor }\end{array}$ & $\begin{array}{l}\text { Pajak } \\
\text { Lainnya }\end{array}$ & Total \\
\hline 1971 & 3,30 & 3,52 & 9,04 & & $-0,11$ & 5,98 & $-3,20$ & 2,29 & 3,15 & 1,12 \\
\hline 1972 & 2,90 & 8,33 & 19,25 & & 8,15 & 4,38 & 1,82 & 3,55 & 2,11 & 0,60 \\
\hline 1973 & 11,64 & 14,09 & 15,38 & & 11,16 & 6,99 & 13,28 & 16,28 & 16,84 & 0,41 \\
\hline 1974 & 14,10 & 23,53 & 5,12 & & 12,29 & 6,47 & 7,23 & 0,52 & 4,06 & 0,43 \\
\hline 1975 & 3,66 & 3,10 & 2,82 & & 3,48 & 1,73 & 4,55 & $-2,43$ & 1,80 & 1,10 \\
\hline 1976 & 3,70 & 4,44 & 4,01 & & 4,39 & 6,50 & 1,87 & 0,91 & $-11,82$ & 0,97 \\
\hline 1977 & 4,21 & 3,37 & 7,82 & & 1,94 & 4,48 & 2,44 & 3,66 & 1,96 & 0,95 \\
\hline 1978 & 2,14 & 2,38 & 5,18 & & 1,76 & 4,07 & 1,46 & 8,13 & 4,01 & 1,07 \\
\hline 1979 & 8,59 & 13,57 & $-16,29$ & & 0,28 & 7,83 & 2,50 & 17,21 & 2,69 & 0,71 \\
\hline 1980 & 8,34 & 10,96 & 6,20 & & 8,42 & 7,80 & 7,85 & $-8,50$ & 7,83 & 0,72 \\
\hline 1981 & 3,74 & 4,69 & 1,52 & & 3,79 & 3,89 & 1,27 & $-30,08$ & 4,62 & 0,93 \\
\hline 1982 & 1,38 & $-0,40$ & 0,84 & & 1,43 & 1,16 & 0,12 & $-3,72$ & 1,15 & 2,74 \\
\hline 1983 & 2,91 & 5,48 & 5,07 & & 2,58 & 4,51 & 2,47 & 3,90 & 2,76 & 1,05 \\
\hline 1984 & 0,48 & $-1,20$ & 3,61 & & 0,93 & 0,81 & $-1,27$ & $-2,89$ & 9,77 & 1,24 \\
\hline 1985 & 0,12 & 1,67 & $-2,52$ & & 5,21 & 0,06 & 1,71 & $-6,67$ & 3,92 & 2,26 \\
\hline 1986 & 2,27 & $-10,36$ & 3,46 & & 2,96 & 1,36 & 5,20 & 4,42 & 0,07 & 1,23 \\
\hline
\end{tabular}


Sambungan Lampiran 6

\begin{tabular}{rcrrrrrrrrr}
\hline Tahun & $\begin{array}{c}\text { PPh } \\
\text { Non Migas }\end{array}$ & $\begin{array}{c}\text { PPh } \\
\text { Migas }\end{array}$ & PBB & BPHTB & $\begin{array}{r}\text { PPN dan } \\
\text { PPn BM }\end{array}$ & Cukai & $\begin{array}{r}\text { Bea } \\
\text { Masuk }\end{array}$ & $\begin{array}{r}\text { Pajak } \\
\text { Ekspor }\end{array}$ & $\begin{array}{c}\text { Pajak } \\
\text { Lainnya }\end{array}$ & Total \\
\hline 1987 & 1,33 & 4,70 & $-1,80$ & & 3,06 & 1,30 & 1,67 & 7,73 & $-0,66$ & 1,12 \\
1988 & 4,88 & $-0,80$ & 5,76 & & 1,72 & 3,01 & $-0,66$ & $-3,89$ & $-1,81$ & 1,05 \\
1989 & 3,87 & 4,83 & 6,75 & & 4,55 & 0,81 & 4,59 & 3,14 & $-5,68$ & 0,98 \\
1990 & 4,48 & 3,64 & 3,42 & & 3,89 & 2,62 & 4,81 & $-49,72$ & 1,74 & 1,27 \\
1991 & 2,38 & $-2,77$ & 2,63 & & 1,76 & 0,94 & 0,39 & $-20,77$ & 4,31 & 1,02 \\
1992 & 2,56 & 0,20 & 1,68 & & 1,71 & 1,67 & 1,25 & $-10,83$ & $-2,11$ & 1,40 \\
1993 & 2,18 & $-3,25$ & 3,66 & & 3,30 & 2,10 & 1,34 & 5,14 & 1,57 & 1,04 \\
1994 & 2,93 & 1,05 & 1,36 & & 2,16 & 2,30 & 1,21 & 12,28 & 0,84 & 1,11 \\
1995 & 1,70 & 2,49 & 2,07 & & 1,70 & 1,95 & $-4,57$ & 4,74 & 5,30 & 0,90 \\
1996 & 3,28 & 2,97 & 3,15 & & 1,32 & 2,30 & $-2,56$ & $-19,02$ & 3,42 & 0,99 \\
1997 & 3,23 & 5,17 & 1,31 & & 2,92 & 2,49 & 2,12 & 5,60 & $-3,58$ & 1,07 \\
1998 & 13,23 & 8,97 & 8,90 & & 3,22 & 11,68 & $-10,32$ & 33,37 & $-5,39$ & 0,44 \\
1999 & 0,82 & 3,83 & $-0,44$ & 0,13 & 2,09 & 3,34 & 5,87 & $-58,37$ & 3,58 & 1,19 \\
2000 & $-6,36$ & 0,25 & $-1,31$ & 0,01 & $-0,65$ & 0,31 & 4,14 & $-19,71$ & 5,74 & 0,93 \\
2001 & 5,40 & 3,46 & 4,41 & 0,07 & 5,54 & 5,05 & 4,81 & 6,75 & 5,00 & 1,32 \\
2002 & 2,00 & $-2,78$ & 2,04 & 0,00 & 1,76 & 2,15 & 1,69 & $-13,56$ & $-1,47$ & 1,64 \\
2003 & 1,77 & $-1,38$ & 1,96 & 0,04 & 1,59 & 1,94 & 0,10 & 2,99 & 3,22 & 1,67 \\
2004 & 2,72 & $-6,21$ & 1,42 & 0,02 & 1,42 & $-0,22$ & $-0,62$ & $-8,70$ & $-7,54$ & 0,59 \\
\hline
\end{tabular}

Keterangan : Tahun 69 menunjukkan tahun anggaran 1969-1970 dan seterusnya, kecuali mulai tahun 2000.

Sumber : IMF, Government Finance Statistics Year Books, Berbagai Tahun(diolah); Depkeu RI, Nota Keuangan dan RAPBN, Berbagai Tahun (diolah); BPS, Indikator Ekonomi, Berbagai Tahun (diolah).

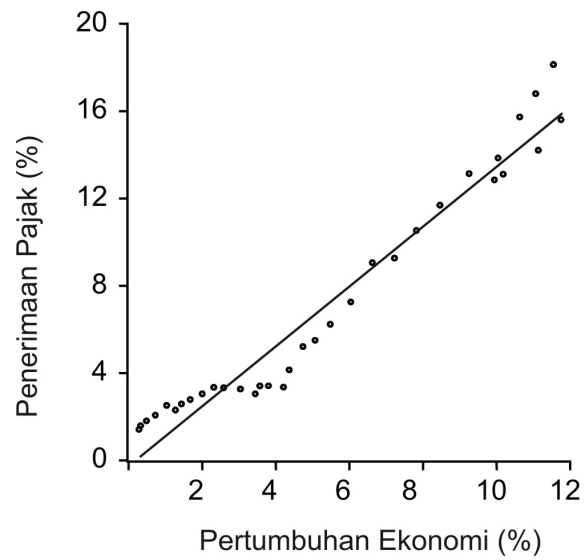

Sumber: Estimasi Regresi antara Penerimaan Pajak dengan PDB tahun 1970 - 2004 dengan menggunakan Metode OLS.

Lampiran 7. Gambar Hubungan Pertumbuhan Ekonomi dengan Penerimaan Pajak1

\footnotetext{
Diagram, pencar ini berdasarkan estimasi model regresi sederhana antara penerimaan pajak terhadap pertumbuhan ekonomi, yang menghasilkan output sebagai berikut:

$\mathrm{TX}=-2.20+0.13$ Growth $\quad$ Adj $\mathrm{R}^{2} 0.95$

$(-6.62) \quad(25.70)$
} 


\title{
PEDOMAN PENULISAN \\ JURNAL EKONOMI PEMBANGUNAN FAKULTAS EKONOMI UNIVERSITAS MUHAMMADIYAH SURAKARTA
}

Terbit: 2 kali dalam setahun pada bulan Juni dan Desember

\author{
Akreditasi Jurnal: \\ KEPUTUSAN DIREKTUR JENDERAL PENDIDIKAN TINGGI \\ KEMENTERIAN PENDIDIKAN NASIONAL NOMOR: 51/DIKTI/Kep./2010 \\ (masa berlaku Juni 2010 s.d Juni 2013)
}

1. Artikel ditulis dengan bahasa Indonesia atau bahasa Inggris dalam bidang kajian masalah ekonomi dan pembangunan.

2. Substansi artikel diharapkan sejalan dengan Panduan Akreditasi Berkala Ilmiah 2006, yang diterbitkan Direktorat Penelitian dan Pengabdian kepada Masyarakat (DP2M) Direktorat Jenderal Pendidikan Tinggi Republik Indonesia).

3. Artikel ditulis dengan kaidah tata bahasa Inggris ataupun bahasa Indonesia yang baik dan benar.

4. Sistematika Penulisan

Sistematika penjenjangan atau peringkat judul artikel dan bagian-bagiannya dilakukan dengan cara berikut:

(1) Judul ditulis dengan huruf besar semua, di bagian tengah atas pada halaman pertama

(2) Sub Bab Peringkat 1 ditulis dengan huruf pertama besar semua di tengah/center

(3) Sub Bab Peringkat 2 ditulis dengan huruf besar-kecil rata tepi kiri

- Sistematika artikel hasil penelitian adalah: judul; nama penulis (tanpa gelar akademik); nama dan alamat institusi, alamat e-mail penulis, abstrak (maksimum 150 kata) yang berisi tujuan, metode, dan hasil penelitian; kata kunci (4-5 kata kunci); pendahuluan (tanpa ada subjudul) yang berisi latar belakang, sedikit tinjauan pustaka, dan tujuan penelitian; metode; hasil penelitian dan pembahasan; kesimpulan; daftar rujukan (hanya memuat sumber-sumber yang dirujuk).

\section{JUDUL UTAMA:}

\section{Sub Judul}

Penulis $1^{1}$ dan Penulis $2^{2}$

${ }^{1}$ Nama instansi/lembaga Penulis 1

Alamat lengkap instansi penulis, nomor telepon instansi penulis

${ }^{2}$ Nama instansi/lembaga Penulis 2

Alamat lengkap instansi penulis, nomor telepon instansi penulis

(jika nama instansi penulis 1 dan 2 sama, cukup ditulis satu saja)

E-mail penulis 1 dan 2:

Abstrak: Abstrak dalam bahasa Indonesia (125 - 150 kata)

Kata kunci: 4 - 5 katal frase

Abstract: Abstract in english (125 - 150 words)

Keywords: $4-5$ words/ phrase

\section{PENDAHULUAN}

(berisi latar belakang, sekilas tinjauan pustaka, dan tujuan penelitian, yang dimasukkan dalam paragraf paragraf bukan dalam bentuk subbab)

METODE PENELITIAN

Subbab

Subbab

...

\section{HASIL ANALISIS DAN PEMBAHASAN}

Pedoman Penulisan Jurnal Ekonomi Pembangunan FE Universitas Muhammadiyah Surakarta 


\title{
Subbab
}

\section{KESIMPULAN \\ DAFTAR PUSTAKA}

- Sistematika artikel hasil pemikiran adalah: judul; nama penulis (tanpa gelar akademik); nama dan alamat institusi, alamat e-mail penulis, abstrak (maksimum 150 kata); kata-kata kunci (4-5 kata kunci); pendahuluan (tanpa ada subjudul) yang berisi latar belakang dan tujuan atau ruang lingkup tulisan; bahasan utama (dapat dibagi ke dalam beberapa sub-judul); penutup atau kesimpulan; daftar rujukan (hanya memuat sumber-sumber yang dirujuk).

\section{JUDUL UTAMA: \\ Sub Judul}

Penulis $1^{1}$ dan Penulis $2^{2}$

${ }^{1}$ Nama instansi/lembaga Penulis 1

Alamat lengkap instansi penulis, nomor telepon instansi penulis

${ }^{2}$ Nama instansi/lembaga Penulis 2

Alamat lengkap instansi penulis, nomor telepon instansi penulis

(jika nama instansi penulis 1 dan 2 sama, cukup ditulis satu saja)

E-mail penulis 1 dan 2 :

\author{
Abstrak: Abstrak dalam bahasa Indonesia (125--150 kata) \\ Kata kunci: 4 - 5 katal frase \\ Abstract: Abstract in english (125 - 150 words) \\ Keywords: $4-5$ words/ phrase

\section{PENDAHULUAN PEMBAHASAN \\ KESIMPULAN} \\ DAFTAR PUSTAKA
}

5. Artikel diketik pada kertas kwarto berkualitas baik. Dibuat sesingkat mungkin sesuai dengan subyek dan metode penelitian (bila naskah tersebut ringkasan penelitian), biasanya 20-25 halaman dengan spasi satu, untuk kutipan paragraf langsung diindent (tidak termasuk daftar pustaka).

6. Marjin atas, bawah, dan samping harus dibuat paling tidak satu inci.

7. Abstrak, ditulis satu paragraf sebelum isi naskah. Abstrak dalam dua bahasa yaitu bahasa Indonesia dan bahasa Inggris. Abstrak tidak memuat uraian matematis, dan mencakup esensi utuh penelitian, metode dan pentingnya temuan dan saran atau kontribusi penelitian.

8. $\quad$ a. Penulisan numbering diintegrasikan dalam paragraf, contohnya:

Tujuan dilakukannya penelitian ini adalah: (1) Untuk mengetahui apakah CSR berpengaruh positif terhadap nilai perusahaan, (2) Untuk mengetahui apakah persentase kepemilikan manajemen berperan sebagai variabel moderating dalam hubungan antara CSR dengan nilai perusahaan, dan (3) Untuk mengetahui apakah tipe industri berperan sebagai variabel moderating dalam hubungan antara CSR dengan nilai perusahaan?

b. Penulisan bullet juga diintegrasikan dalam paragraf dengan menggunakan tanda koma pada antarkata/kalimat tanpa bullet.

9. Tabel dan gambar, untuk tabel dan gambar (grafik) sebagai lampiran dicantumkan pada halaman sesudah teks. Sedangkan tabel atau gambar baik di dalam naskah maupun bukan harus diberi nomor urut.

- Tabel atau gambar harus disertai judul. Judul tabel diletakkan di atas tabel sedangkan judul gambar diletakkan di bawah gambar.

Pedoman Penulisan Jurnal Ekonomi Pembangunan FE Universitas Muhammadiyah Surakarta 
- Sumber acuan tabel atau gambar dicantumkan di bawah tabel atau gambar.

- Garis tabel yang dimunculkan hanya pada bagian header dan garis bagian paling bawah tabel sedangkan untuk garis-garis vertikal pemisah kolom tidak dimunculkan.

Contoh: Tabel

Tabel 1. Bentuk-bentuk Mobilitas Penduduk

\begin{tabular}{llll}
\hline No & Bentuk Mobilitas & Batas Wilayah & Batas Waktu \\
\hline 1. & Ulang-alik (commuting) & Dukuh (dusun) & 6 jam atau lebih dan kembali pada hari yang sama \\
2. & Menginap/mondok di daerah tujuan & Dukuh (dusun) & Lebih dari satu hari tetapi kurang dari 6 bulan \\
3. & Permanen/menetap di daerah tujuan & Dukuh (dusun) & 6 bulan atau lebih menetap di daerah tujuan \\
\hline
\end{tabular}

Sumber: Ida Bagoes, 2000

\section{Contoh: Gambar}

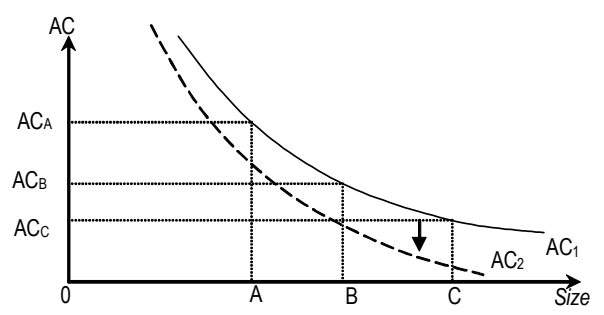

Sumber: Saunders (1997: 291)

Gambar 2. Dampak Peningkatan Teknologi

10. Cara penulisan rumus, Persamaan-persamaan yang digunakan disusun pada baris terpisah dan diberi nomor secara berurutan dalam parentheses (justify) dan diletakkan pada margin kanan sejajar dengan baris tersebut. Contoh:

$\mathrm{wt}=\mathrm{f}\left(\mathrm{y}_{\mathrm{t}}, \mathrm{k}_{\mathrm{t}}, \mathrm{w}_{\mathrm{t}-1}\right)$

11. Keterangan Rumus ditulis dalam satu paragraf tanpa menggunakan simbol sama dengan (=), masingmasing keterangan notasi rumus dipisahkan dengan koma. Contoh:

Dimana $\mathbf{w}$ adalah upah nominal, $\mathbf{y t}$ adalah produktivitas pekerja, kt adalah intensitas modal, $\mathbf{w}_{\mathbf{t}-\mathbf{1}}$ adalah tingkat upah periode sebelumnya.

12. Perujukan sumber acuan di dalam teks dengan menggunakan nama akhir dan tahun. Kemudian bila merujuk pada halaman tertentu, penyebutan halaman setelah penyebutan tahun dengan dipisah titik dua. Untuk karya terjemahan dilakukan dengan cara menyebutkan nama pengarang aslinya.

Contoh:

- Yuni (2008: 23) memandang bahwa .....

- Fatimah dan Daryono (1997) menunjukkan adanya ....

- Didit dkk (2007) berkesimpulan bahwa....

- Untuk meningkatkan perekonomi daerah .... (Yuni, Triyono, dan Agung Riyardi, 2009).

- Maya (2009) berpendapat bahwa ....

13. Setiap kutipan, baik langsung maupun tidak langsung, harus diikuti sumbernya (lihat poin no. 10) dan dicantumkan juga dalam daftar pustaka. Contoh:

Di dalam paragraf isi tercantum kutipan dari: Buiter (2007:15) berpendapat bahwa...

Maka dalam daftar pustaka harus ada sumber referensinya seperti berikut:

Buiter, W. H., (2002). The Fiscal Theory of the Price Level: A Critique, Economic Journal, 112(127): 459-480.

Pedoman Penulisan Jurnal Ekonomi Pembangunan FE Universitas Muhammadiyah Surakarta 
14. Sedapat mungkin pustaka-pustaka yang dijadikan rujukan adalah pustaka yang diterbitkan 10 tahun terakhir dan diutamakan dari jurnal ilmiah.

15. Unsur yang ditulis dalam daftar pustaka secara berturut-turut meliputi: (1) nama akhir pengarang, nama awal, nama tengah, tanpa gelar akademik, (2) tahun penerbitan, (3) judul termasuk subjudul, (4) tempat penerbitan, (5) nama penerbit.

Contoh cara penulisan:

a. Format rujukan dari buku: Nama pengarang, (tahun), Judul Buku, edisi, Kota penerbit, Nama penerbit. Jika penulis sebagai editor tunggal, ditulis (Ed.) di belakang namanya. Ditulis (Eds.) jika editornya lebih dari satu orang. Kemudian bila pengarang lebih dari tiga orang, dituliskan nama pengarang pertama dan yang lain disingkat 'dkk' (pengarang domestik) atau 'et.al.' (pengarang asing).

Enders, W., (2004), Applied Econometric Time Series, Second edition, New York: John Wiley \& Sony Inc. Purnomo, Didit (Ed.). (2005). The Role of Macroeconomic Factors in Growth. Surakarta: Penerbit Muhamadiyah University Press.

b. Format rujukan dari artikel dalam buku ditulis: Nama editor (Ed.), (tahun), Judul tulisan/karangan. Judul buku, hlm atau pp., kota penerbit: nama penerbit

Daryono (Ed.). (2005). Concept of Fiscal Decentralization and Worldwide Overview (hlm. 12-25). Surakarta: Penerbit Muhammadiyah University Press.

c. Format rujukan dari artikel dalam jurnal/majalah/koran: Nama pengarang (tahun). judul tulisan/ karangan. Nama jurnal/majalah/koran, hlm atau pp., volume (nomor), halaman. Jika rujukan koran tanpa penulis, nama koran ditulis diawal.

Rodden, J., (2002). The dilemma of Fiscal Federalism: Grants and Fiscal Performance arround the World. American Journal of Political Science, 46 (3): 670-687.

Triyono (2008). Perimbangan Keuangan Pusat dan Daerah Sebagai Pelaksanaan Desentralisasi Fiskal Efek. Warta Ekonomi, Vol. 4, Agustus: 46-48.

Haryanto, S., (2007, 13 November). Desentralisasi Fiskal dan Pembangunan Ekonomi. Harian Jakarta, hlm.4.

Harian Jogjakarta, (2007, 1 April). Hubungan Keuangan Pusat-Daerah di Indonesia. hlm. 4.

d. Format rujukan dari internet, tanggal akses dicantumkan.

Setyowati, E.,. Keuangan Publik dan Sistem Harga. http://www.ekonomipublik.com/akt/pdf/akt452.pdf.

Diakses tanggal 27 Mei 2009.

\section{Pengiriman Artikel}

1. Artikel dikirimkan sebanyak 2 eksemplar hardcopy, dan softcopy berupa file. File bisa dikirim melalui email jepums@yahoo.co.id atau dalam media cd.

2. Artikel yang dikirim wajib dilampiri biodata ringkas pendidikan termasuk catatan riwayat karya-karya ilmiah sebelumnya yang pernah dipublikasikan, insitusi dan alamatnya, nomor telpon kontak atau e-mail penulis.

3. Penulis yang menyerahkan artikelnya kepada editor atau penerbit, harus menjamin bahwa naskah yang diajukan tidak melanggar hak cipta, belum dipublikasikan atau telah diterima untuk dipublikasi oleh jurnal lainnya.

4. Kepastian pemuatan atau penolakan naskah akan diberitahukan secara tertulis. Penulis yang artikelnya dimuat mendapatkan jurnal tersebut. Artikel yang tidak dimuat tidak akan dikembalikan.

\section{Alamat Redaksi Jurnal Ekonomi Pembangunan Fakultas Ekonomi Universitas Muhammadiyah Surakarta: \\ Redaksi Jurnal Ekonomi Pembangunan Fakultas Ekonomi Universitas Muhammadiyah Surakarta Jalan A. Yani Tromol Pos I Pabelan SURAKARTA 57102 Telp. 0271-717417 psw 229}

Pedoman Penulisan Jurnal Ekonomi Pembangunan FE Universitas Muhammadiyah Surakarta 
TENTANG JURNAL:

\title{
JURNAL EKONOMI PEMBANGUNAN
}

Kajian Masalah Ekonomi dan Pembangunan

ISSN 1411- 6081

\author{
Pimpinan Redaksi \\ Didit Purnomo
}

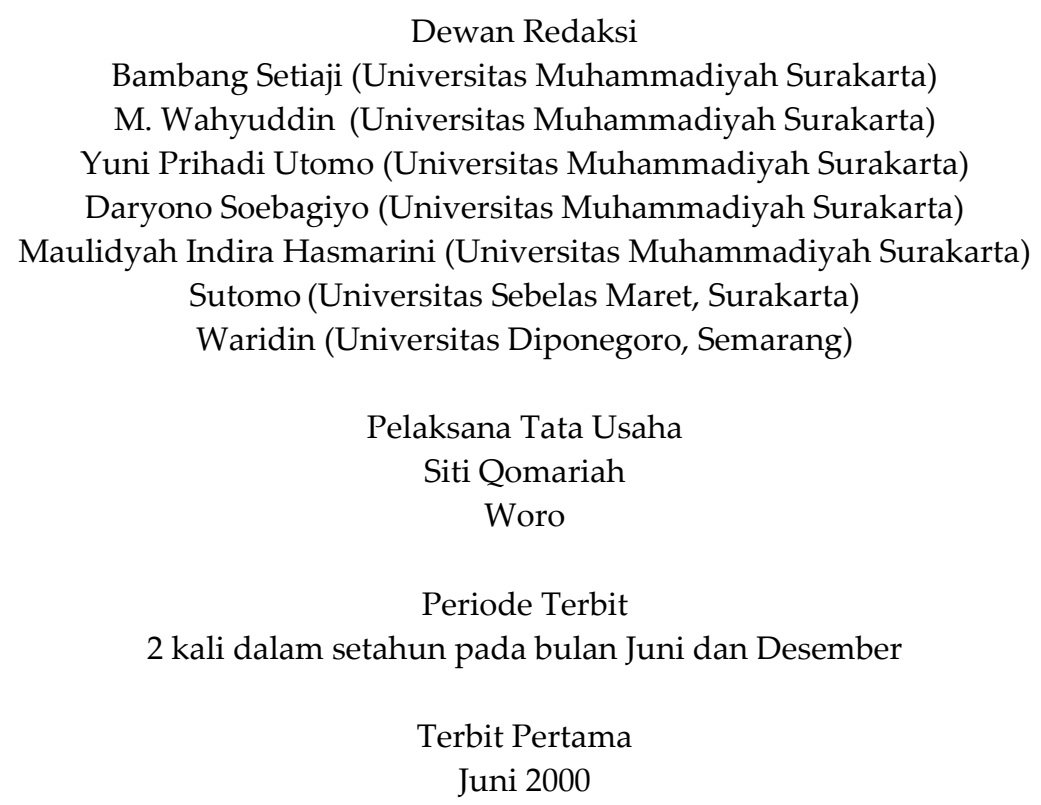

Jurnal EKONOMI PEMBANGUNAN merupakan jurnal ilmiah yang berisikan hasil penelitian dan kajian teoritis mengenai masalah-masalah ekonomi dan pembangunan, khususnya di Indonesia. Diterbitkan oleh Balai Penelitian dan Pengembangan Ekonomi Fakultas Ekonomi Universitas Muhammadiyah Surakarta.

Redaksi menerima sumbangan tulisan yang belum pernah diterbitkan atau dalam proses terbit oleh media lain. Naskah diketik di atas kertas HVS kuarto spasi satu sepanjang lebih kurang 20-25 halaman, dengan format seperti tercantum pada prasyarat naskah jurnal EKONOMI PEMBANGUNAN di halaman belakang. Naskah yang masuk akan dievaluasi dan disunting untuk keseragaman format dan tata cara lainnya.

Alamat Penyunting dan Tata Usaha: Subag Tata Usaha Fakultas Ekonomi Universitas Muhammadiyah Surakarta, Jl. A. Yani, Tromol Pos 1, Pabelan, Surakarta 57102; Telpon (0271) 717417 psw 229,

E-mail: jepums@yahoo.co.id

Website: http://www.ums.ac.id atau http://www.paradejurnal.wordpress.com

Simak informasi jurnal: http://www.paradejurnal.wordpress.com

Admin: Mirat Sidharta. SE

Pedoman Penulisan Jurnal Ekonomi Pembangunan FE Universitas Muhammadiyah Surakarta 